\author{
EwA BIEŃKOWSKA
}

Europejska Wyższa Szkoła Prawa i Administracji w Warszawie

\title{
FUNDUSZ POMOCY POKRZYWDZONYM \\ ORAZ POMOCY POSTPENITENCJARNEJ \\ - O NOWEJ INSTYTUCJI PRAWA KARNEGO \\ WYKONAWCZEGO KRYTYCZNIE
}

\section{WPROWADZENIE}

Pod koniec ub. wieku w Ministerstwie Sprawiedliwości zapoczątkowane zostały działania mające na celu powołanie do życia państwowego funduszu kompensacyjnego dla ofiar przestępstw. Uznano bowiem, że najwyższy już czas, aby Polska dołączyła do tych państw członkowskich Rady Europy, które czynią zadość wymogom Europejskiej Konwencji o kompensacji dla ofiar przestępstw popełnionych z użyciem przemocy z 24 listopada 1983 r. ${ }^{1}$ Skonstatowano nadto, że nade-

1 Zob. polski tekst Konwencji w: E. BieńKowsKa, C. Kulesza, Jak postępować z ofiarami przestępstw? Dokumenty Rady Europy i Narodów Zjednoczonych. Poradnik dla praktyków, Białystok 1992, s. 49 i n.; TYcHżE, Europejskie standardy postepowania z ofiarami przestępstw, Białystok 1997, s. 64 i n.; Standardy Rady Europy. Teksty i komentarze, III: Prawo karne, pod red. E. ZIELIŃskIEJ, Warszawa 1997, s. 500 i n.; T. CIELECKI, Ofiaryprzestepstwwprewencyjnejstrategiiprzeciwdziałaniaprzestępczości, Słupsk 1999, s. 57 i n.; E. BiEŃKOwsKa, Wiktymologia. Zarys wykładu, Warszawa 2000, s. 109 i n.; E. Bieńkowska, L. MAzowieckA, Prawa ofiar przestęstw, Warszawa 2009, s. 198 i n.; TYchżE, Ofiara przestępstwa $w$ dokumentach międzynarodowych, Warszawa 2009, s. 78 i n.; TYchżE, Państwowa kompensata przysługujaca ofiarom niektórych przestęstw. Komentarz, Warszawa 2011, s. 187 i n. 
szła także pora na wyłączenie kwestii dotyczących pomocy dla ofiar przestępstw z unormowań o pomocy postpenitencjarnej dla pozbawionych wolności i ich rodzin, w których - ze zrozumiałych względów - pokrzywdzonym przyznaje się status uprawnionych gorszego, „drugiego gatunku”. Niemniej, Polska była jedynym spośród europejskich państw przynależnych do tzw. Bloku Wschodniego, w którym w ogóle dostrzeżono, i to wcześnie, potrzebę zapewnienia ofiarom przestępstw jakiegoś, choćby minimalnego, wsparcia finansowego ze strony państwa.

Przypomnijmy, że takie rozwiązanie pojawiło się już w pierwszej połowie lat 70. XX w., kiedy wdrażanie idei kompensacji państwowej dla ofiar przestępstw w poszczególnych państwach świata zachodniego znajdowało się jeszcze w dość wstępnym stadium ${ }^{2}$. W $\S 15$ ust. 1 rozporządzenia Prezesa Rady Ministrów z 29 maja 1974 r. w sprawie pomocy postpenitencjarnej ${ }^{3}$ znalazł się zapis, stosownie do którego „Ze środków przeznaczonych na cele pomocy postpenitencjarnej może być udzielana w razie potrzeby pomoc dla osób pokrzywdzonych przestępstwem i ich rodzin". Regulacja taka, w nieco zmienionym brzmieniu, znalazła się także w k.k.w. z 1997 r., który na mocy art. $43 \S 1$ powołał do życia Fundusz Pomocy Postpenitencjarnej. W myśl § 4 zd. 2 tego przepisu „W wyjątkowych wypadkach ze środków tych [tj. ze środków Funduszu - E.B.] można udzielać pomocy również osobom pokrzywdzonym przestępstwem i ich rodzinom". Szczegółowo kwestie dotyczące funkcjonowania Funduszu regulowało rozporządzenie Ministra Sprawiedliwości z 22 kwietnia $2005 \mathrm{r}^{4}$

Słusznie podniósł S. Lelental, że - gdy chodzi o udzielanie pomocy osobom pokrzywdzonym i ich rodzinom - „Ocena, czy in concreto zachodzi wyjątkowy wypadek, pozostawiona została swobodnemu uznaniu podmiotów udzielających pomocy. Przepis art. $43 \S 4 \mathrm{KKW}$ nie stanowi bowiem o żadnych kryteriach tej pomocy, a FPPR [tj. cyt. rozporządzenie z 22 kwietnia 2005 r. - E.B.] wręcz pomija warunek

2 Szerzej zob. E. BieńKowska, Komentarz, [w:] Standardy..., s. 504 i n.

3 Dz.U. Nr 21, poz. 126 ze zm.

${ }^{4}$ Dz.U. Nr 69, poz. 618. 
wyjątkowości jej udzielania osobom pokrzywdzonym przestępstwem i ich rodzinom. W tym zakresie obowiązujące unormowanie zasługuje na krytykę. Ma ona swoje źródło w tym, że przepis art. $43 \S 6 \mathrm{KKW}$ nie zawiera wymaganych w art. 92 ust. 1 Konstytucji RP wytycznych co do treści aktu wykonawczego, a akt wykonawczy (FPPR) nie tylko, że nie stanowi o wyjątkowym charakterze pomocy udzielanej z Funduszu pokrzywdzonym przestępstwem i ich rodzinom, ale również nie ustala dyrektyw jej udzielania"s.

Odrębny, samoistny mechanizm kompensowania ofiar przestępstw został utworzony dopiero w 2005 r. ${ }^{6}$. Początkowo obejmował on swoim zasięgiem ofiary umyślnych przestępstw popełnionych z użyciem przemocy pod warunkiem, że doznały następstw opisanych w art. 156 $\S 1$ lub 157 § 1 k.k. Na mocy nowelizacji z 2009 r. ${ }^{7}$ poszerzono grono uprawnionych, rezygnując z przesłanki umyślności i popełnienia przestępstwa $\mathrm{z}$ użyciem przemocy. Istniejący system kompensacyjny posiada jednak istotne mankamenty. Został on bowiem wprowadzony nie tyle dlatego, że uznano, iż uprawnienie do państwowej kompensaty jest niezwykle ważne w procesie przezwyciężania skutków przestępstwa, ile z tego względu, że taki był wymóg prawa unijnego. W efekcie przyjęto rozwiązania minimalistyczne, a w dodatku - rozwiązania złe, niezapewniające ofiarom przestępstw należytego dostępu do kompensaty od państwa ${ }^{8}$. W praktyce - jak dowodzą tego badania - obowiązujące regulacje również się nie sprawdzają . Potwierdza to wniosek o ich wadliwości, jak też braku zrozumienia istoty i wagi kompensaty.

5 S. Lelental, Kodeks karny wykonawczy. Komentarz, Warszawa 2010, s. 211.

${ }^{6}$ Zob. ustawa z 7 lipca 2005 r. o państwowej kompensacie przysługującej ofiarom niektórych przestępstw, Dz. U. Nr 169, poz. 1415 ze zm.

7 Dz. U. Nr 79, poz. 665.

${ }^{8}$ Zob. szerzej E. BieńKowska, L. Mazowiecka, Państwowa kompensata..., s. 57 i n.

9 Zob. M. NieŁaczna, Kompensata dla ofiar przestepstw. Prawo a praktyka. Raport $z$ monitoringu działania ustawy o państwowej kompensacie dla ofiar niektórych przestęstw umyślnych, Warszawa 2007, s. 107 i n.; S. ŁaGoszińsKi, Praktyka przyznawania świadczeń na podstawie ustawy z 7.07.2005 r. o państwowej kompensacie przystugujacej ofiarom niektórych przestępstw, «Prawo w działaniu»9/2011, Sprawy 
Parę lat później ustawą z 12 lutego 2010 r. ${ }^{10}$ znowelizowano art. 43 k.k.w., na mocy którego - w miejsce Funduszu Pomocy Postpenitencjarnej - utworzony został Fundusz Pomocy Pokrzywdzonym oraz Pomocy Postpenitencjarnej. Regulacja ta miała wejść w życie 1 lipca 2011 r. W okresie vacatio legis ustawodawca dostrzegł jednak potrzebę jej zmiany, co nastapiło na mocy ustawy z 15 kwietnia 2011 r. ${ }^{11}$. Obowiązuje ona od 30 czerwca 2011 r. przewidując, że unormowania dotyczące Funduszu wchodzą w życie 1stycznia 2012 r.

Nieuchronnie nasunęło się pytanie o to, czym w istocie jest ta nowa instytucja, w szczególności - czy przypadkiem nie jakimś drugim mechanizmem kompensowania ofiar przestępstw, jak też o to, dlaczego została niejako wpleciona w mechanizm niesienia pomocy postpenitencjarnej, w efekcie czego znalazła się w regulacji karno wykonawczej.

W Uzasadnieniu projektu ustawy z 12 lutego 2010 r. czytamy, iż „Projektowana ustawa zakłada połączenie w jednym funduszu źródła finansowania działań ukierunkowanych na poprawę sytuacji osób pokrzywdzonych przestępstwem oraz pomoc postpenitencjarną. Połączenie obu tych zadań wydaje się racjonalne, nie ma bowiem uzasadnienia, aby funkcjonowały dwa oddzielne fundusze, skoro dysponentem każdego z nich ma być Minister Sprawiedliwości. Scentralizowanie środków w jednym Funduszu pozwoli ponadto na prowadzenie spójnej i przejrzystej polityki pomocy pokrzywdzonym oraz skazanym, a ponadto na zachowanie uzasadnionych interesem społecznym prawidłowych proporcji w tym zakresie”. I dalej: „Połączenie zadań odnoszących się do osób pokrzywdzonych oraz skazanych w jednym funduszu zapewni racjonalne wydatkowanie środków finansowych oraz przyniesie budżetowi państwa wymierne oszczędności z tytułu zmniejszenia kosztów obsługi w porównaniu z sytuacją, w której funkcjonowałyby dwa oddzielne fundusze: Fundusz Pomocy Pokrzywdzonym oraz istniejący obecnie Fundusz

karne, s. 119 i n.; L. MazowieckA, Państwowa kompensacja dla ofiar przestęstw w Polsce na tle standardów międzynarodowych, Warszawa 2012, s. 200 in.

${ }_{10}$ Dz. U. Nr 40, poz. 227.

${ }^{11}$ Dz. U. Nr 129, poz. 734. 
Pomocy Postpenitencjarnej" ${ }^{12}$. W tej ostatniej kwestii projektodawca wskazuje jednak, że ,Z uwagi na znaczną liczbę spraw, którymi będą musieli zająć się pracownicy Ministerstwa Sprawiedliwości, konieczne będzie uruchomienie nowych etatów do obsługi Funduszu. W 2006 r. nawiązki oraz świadczenia pieniężne orzeczono w około 20.000 spraw. Jeżeli natomiast rozszerzy się taką możliwość orzekania nawiązek także o sprawy, w których stosuje się warunkowe umorzenie, należy przyjąć, że liczba ta może wzrosnać do co najmniej 30.000 spraw rocznie. Oznacza to, że taka liczba odpisów orzeczeń zostanie przez sądy nadesłana do Ministerstwa Sprawiedliwości. Musi to skutkować dodatkowymi etatami, w związku z koniecznością przyjęcia zwiększonej liczby korespondencji przez kancelarię główną Ministerstwa, obowiązkiem dostarczenia odpisów orzeczeń do właściwej komórki merytorycznej, zarejestrowania wszystkich spraw, monitorowania wpłaty nawiązek i świadczeń, a wreszcie uruchomienia procedury egzekucyjnej w sytuacji braku realizacji należności. Konieczne będzie także rozpoznawanie wniosków nadsyłanych przez uprawnione podmioty, przygotowywanie opinii dla Ministra Sprawiedliwości, opracowywanie projektów stosownych umów, a następnie kontrola ich realizacji... W związku z powyższym przewiduje się wzmocnienie etatowe o 6-7 osób... Łączne wydatki roczne związane z zatrudnieniem dodatkowych osób szacowane są na około 312000 zł."13.

Pytanie, gdzie te oszczędności, o których wspomina się w Uzasadnieniu? Podkreślić zarazem należy, że obowiązkami dotyczącymi egzekwowania zasądzonych nawiązek i świadczeń pieniężnych - na mocy nowelizacji z 15 kwietnia 2011 r. - obciążone zostały sądy orzekające te środki karne. Dla nich jednak dodatkowych etatów nie przewidziano.

Rozważmy zatem, czym jest w istocie nowy Fundusz, a zwłaszcza, jaka jest relacja pomiędzy jego oboma członami i czy rzeczywiście uzasadnione było ich połączenie.

12 Druk sejmowy nr 1854, s. 1.

13 J.w., Ocena skutków regulacji..., s. 17. 
Podstawowy w omawianym zakresie przepis art. 43 k.k.w. skonstruowano w sposób budzący poważne zastrzeżenia. Oto bowiem na wstępie reguluje on kwestię wtórną, jaką jest egzekwowanie nawiązek i świadczeń pieniężnych zasądzonych na rzecz Funduszu, określając dopiero później źródła jego przychodów. Następnie wskazuje, jakie są zadania tej instytucji oraz zasady jej funkcjonowania. Wydaje się natomiast, że kwestią podstawową, którą należałoby sprecyzować na samym początku, powinno być przedstawienie celów, dla jakich Fundusz został powołany do życia. Ponadto zanim rozstrzygnie się o zagadnieniach związanych z egzekwowaniem określonych orzeczeń na rzecz Funduszu, trzeba wskazać źródła jego dochodów. Dodajmy też, że regulacja kodeksowa jest bardzo ogólna i niewiele mówi o faktycznym kształcie omawianej instytucji. Bez zapoznania się z treścią przepisów wykonawczych wiedza o niej może być wręcz fałszywa. Rodzi to wątpliwości co do poprawności legislacyjnej przyjętego unormowania.

Rozporządzenie wykonawcze zostało podpisane przez Ministra Sprawiedliwości 3 stycznia 2012 r. $^{14}$, a weszło w życie - stosownie do jego $§ 22-$ z dniem ogłoszenia, czyli 13 stycznia 2012 r. ${ }^{15}$. Nastapiło to więc $\mathrm{z}$ pewnym opóźnieniem w stosunku do dnia wejścia $\mathrm{w}$ życie art. 43 k.k.w. w nowo nadanym mu brzmieniu, który w tym kształcie przypomnijmy - obowiązuje od 1 stycznia $2012 \mathrm{r}$.

Przyjrzyjmy się zatem wprowadzonym rozwiązaniom. Ich dość szczegółowe zaprezentowanie jest niezbędne. Pozostają one bowiem jeszcze w zasadzie nieznane, a przy tym w części dotyczącej pokrzywdzonych stanowią zupełną nowość. Dopiero wtedy możliwe będzie dokonanie analizy, która pozwoli na udzielenie odpowiedzi na postawione pytanie: czym w istocie jest Fundusz Pomocy Pokrzywdzonym oraz Pomocy Postpenitencjarnej i czy faktycznie istniały przesłanki przemawiające za jego utworzeniem.

14 Poprzedzały je projekty: z 28 czerwca 2011 r. i 15 września 2011 r.

15 Dz. U. Nr 9, poz. 49. 


\section{OPIS UNORMOWANIA FUNDUSZU}

\subsection{Charakter prawny}

Jak stanowi $\S 2$ art. 43 k.k.w., „Fundusz jest państwowym funduszem celowym, którego dysponentem jest Minister Sprawiedliwości”.

\subsection{Zadania i środki finansowania}

Zadania, jakie ma realizować Fundusz, ustawodawca opisał w $\S 8$ art. 43 k.k.w. Znalazły się wśród nich następujące:

1) pomoc osobom pokrzywdzonym przestępstwem oraz członkom ich rodzin, zwłaszcza pomoc medyczna, psychologiczna, rehabilitacyjna, prawna i materialna, udzielana przez jednostki niezaliczane do sektora finansów publicznych i niedziałające w celu osiagnnięcia zysku, w tym stowarzyszenia, fundacje, organizacje i instytucje;

2) pomoc postpenitencjarna osobom pozbawionym wolności zwalnianym z zakładów karnych i aresztów śledczych oraz członkom ich rodzin udzielana przez zawodowych kuratorów sądowych i Służbę Więzienną;

3) pomoc postpenitencjarna osobom pozbawionym wolności zwalnianym z zakładów karnych i aresztów śledczych oraz członkom ich rodzin udzielana przez stowarzyszenia, fundacje, organizacje i instytucje, których celem jest współdziałanie w wykonywaniu orzeczeń i pomoc w readaptacji skazanych, jak też pomoc udzielana im przez kościoły i inne związki wyznaniowe oraz osoby godne zaufania (art. $38 \S 1$ k.k.w.);

4) działalność podejmowana lub powierzona przez dysponenta Funduszu mająca na celu wsparcie i rozwój systemu pomocy osobom pokrzywdzonym przestępstwem oraz pomocy postpenitencjarnej, a w tym: promowanie i wspieranie inicjatyw oraz przedsięwzięć służących poprawie sytuacji osób pokrzywdzonych przestępstwem oraz skutecznej readaptacji skazanych; podejmowanie przedsięwzięć o charakterze edukacyjnym i informacyjnym; pokrywanie kosztów związanych z organizowaniem i prowadzeniem szkoleń; podejmowanie, 
organizowanie i zlecanie badań naukowych dotyczących sytuacji oraz potrzeb osób pokrzywdzonych przestępstwem oraz osób skazanych.

Z kolei źródła, z których mają pochodzić środki finansowe przeznaczone na realizację wskazanych zadań, zostały wyszczególnione w $§ 3$ art. 43 k.k.w. Należą do nich:

- nawiązki i świadczenia pieniężne orzekane przez sądy;

- 10-procentowe potrącenia z wynagrodzeń przysługujących za pracę skazanym zatrudnionym na podstawie skierowania do pracy albo umowy o pracę, umowy zlecenia, umowy o dzieło, umowy o pracę nakładczą, a także na innej podstawie prawnej (art. 121 $\S 2$ k.k.w.);

- środki pochodzące z wykonania kar dyscyplinarnych w postaci obniżenia - nie więcej niż o 25\% na okres do 3 miesięcy - przypadającej skazanemu części wynagrodzenia za pracę (art. $143 \S 1$ pkt 7 k.k.w.);

- spadki, zapisy i darowizny oraz

- dotacje, zbiórki i inne.

Dopiero przepisy wykonawcze precyzują, które ze wskazanych źródeł finansowania Funduszu przeznaczone są na realizację poszczególnych zadań. Okazuje się bowiem, że środki pochodzące z określonych źródeł zostały przypisane konkretnym zadaniom. Najogólniej sprowadza się to do tego, że $z$ innych podstawowych źródeł jest finansowana pomoc udzielana pokrzywdzonym i członkom ich rodzin, a z innych osobom pozbawionym wolności i zwalnianym $\mathrm{z}$ jednostek penitencjarnych oraz członkom rodzin tych osób.

\subsubsection{Zadania w zakresie niesienia pomocy pokrzywdzonym}

i źródła ich finansowania

W rozdziale 2. rozporządzenia znalazły się szczegółowe regulacje dotyczące zadań w zakresie udzielania pomocy pokrzywdzonym i ich rodzinom oraz środków służących ich finansowaniu. W § 11 wskazuje się, że na realizację tego celu przeznaczone są środki pochodzące $\mathrm{z}$ orzeczonych przez sądy nawiązek i świadczeń pieniężnych, jak też uzyskane ze spadków, zapisów, darowizn, dotacji, zbiórek i innych źródeł. Podkreślić należy, iż pierwotnie na cele związane ze świad- 
czeniem pomocy pokrzywdzonym miały być przeznaczane wyłącznie środki pozyskane $\mathrm{z}$ orzeczonych nawiązek i świadczeń pieniężnych. Było to co najmniej dziwne: dlaczego bowiem nie można byłoby np. uczynić zapisu na ten cel, a jedynie na pomoc postpenitencjarną?

Ustawa nowelizacyjna z 12 lutego 2010 r. przewidziała, iż orzekanie wspomnianych dwóch rodzajów środków karnych na rzecz Funduszu może mieć miejsce w ściśle oznaczonych sytuacjach. W szczególności nawiązki (art. 39 pkt 6 k.k.) mogą być orzekane w kwocie do 100000 złotych (art. 48 k.k.) w następujących przypadkach:

- w razie skazania za umyślne przestępstwo przeciwko życiu lub zdrowiu albo za inne przestępstwo umyślne, którego skutkiem jest śmierć człowieka, ciężki uszczerbek na zdrowiu, naruszenie czynności narządu ciała lub rozstrój zdrowia, a także w razie skazania za sprowadzenie katastrofy (art. 173 k.k.), sprowadzenie bezpośredniego niebezpieczeństwa katastrofy (art. 174 k.k.) lub spowodowanie wypadku przez żołnierza (art. 355 k.k.), jeżeli sprawca był w stanie nietrzeźwości lub pod wpływem środka odurzającego albo zbiegł z miejsca zdarzenia (art. $47 \S 1$ k.k.); oraz

- w razie skazania za występek o charakterze chuligańskim, jeżeli nie został ustalony pokrzywdzony (art. 57a $§ 2$ k.k.).

Natomiast świadczenia pieniężne (art. 39 pkt 7 k.k.) w wysokości nieprzekraczającej 60000 złotych mogą być orzekane wówczas, gdy:

- sąd odstępuje od wymierzenia kary oraz w wypadkach wskazanych w ustawie (art. $49 \S 1$ k.k.), jak też

- ma miejsce skazanie za przestępstwo prowadzenia pojazdu w stanie nietrzeźwości lub pod wpływem środka odurzającego (art. 178a k.k.), dopuszczenia do ruchu pojazdu w stanie bezpośrednio zagrażającym bezpieczeństwu lub dopuszczenie do prowadzenia pojazdu przez osobę znajdującą się w stanie nietrzeźwości, pod wpływem środka odurzającego lub nieposiadającą odpowiednich uprawnień (art. 179 k.k.) lub pełnienia czynności związanych bezpośrednio z zapewnieniem bezpieczeństwa ruchu pojazdów mechanicznych w stanie nietrzeźwości lub pod wpływem środka odurzającego (art. 180 k.k.), o czym mowa w art. 49 § 2 k.k. 
W przypadku warunkowego umorzenia postępowania przewidziana została możliwość orzeczenia alternatywnie bądź świadczenia pieniężnego bądź nawiązki (art. 67 § 3 k.k.). Należy podkreślić w odniesieniu do pierwszego z tych środków karnych, że ustawodawca nie wskazał w tym przypadku jego górnego pułapu. Oznacza to, że ma tu zastosowanie art. 49 § 1 in fine k.k. ustalający maksymalną kwotę świadczenia pieniężnego na poziomie nie wyższym niż 20000 złotych.

Środki pochodzące z orzeczonych na rzecz Funduszu nawiązek i świadczeń pieniężnych, jak też ze spadków, zapisów, darowizn oraz dotacji, zbiórek i z innych źródeł mają być przeznaczone na świadczenie pokrzywdzonym pomocy o dwojakim charakterze.

Mają one służyć - z jednej strony - finansowaniu konkretnej pomocy udzielanej pokrzywdzonym przez jednostki niezaliczane do sektora finansów publicznych i niedziałające w celu osiagnnięcia zysku, jak stowarzyszenia, fundacje, organizacje i instytucje. Stosownie do $§ 11$ rozporządzenia pomoc ta ma polegać na: organizowaniu i finansowaniu pomocy prawnej; pokrywaniu kosztów świadczeń zdrowotnych, wyrobów medycznych, w tym przedmiotów ortopedycznych oraz środków pomocy uprawnionym nieobjętym obowiązkiem ubezpieczenia zdrowotnego, a także świadczeń nieuwzględnionych w wykazach świadczeń gwarantowanych określonych na podstawie art. 31d ustawy z 27 sierpnia 2004 r. o świadczeniach opieki zdrowotnej finansowanych ze środków publicznych ${ }^{16}$, jeżeli jest to niezbędne w procesie leczniczym doznanego uszczerbku na zdrowiu wynikającego z przestępstwa lub jego następstw; pokrywanie kosztów związanych z edukacją ogólnokształcącą i zawodową, także na zasadach indywidualnego kształcenia, odpowiednio do wieku i potrzeb osób uprawnionych; pokrywanie kosztów czasowego zakwaterowania lub udzielania schronienia; finansowanie okresowych dopłat do bieżących zobowiązań czynszowych za lokal mieszkalny, do którego osoba uprawniona posiada tytuł prawny, a lokal ten nie jest użytkowany przez inne osoby; dostosowanie lokalu mieszkalnego lub budynku mieszkalnego do potrzeb osoby pokrzywdzonej przestępstwem w przypadku, gdy utrata sprawności nastąpiła

${ }_{16}$ Tekst jedn. Dz. U. z 2008 r. Nr 164, poz. 1027 ze zm. 
w wyniku przestępstwa; finansowanie przejazdów środkami komunikacji publicznej lub pokrywanie kosztów transportu związanych z uzyskiwaniem świadczeń i regulowaniem wymienionych wcześniej spraw; pokrywanie kosztów żywności lub bonów żywnościowych.

Zrezygnowano z możliwości przyznawania w szczególnie uzasadnionych wypadkach świadczeń pieniężnych na określony cel i okres wskazany przez podmiot udzielający pomocy. W ten sposób nie można już w zasadzie mówić o tym, że mamy do czynienia z drugim systemem kompensacyjnym.

Koszyk świadczeń zdrowotnych określają rozporządzenia Ministra Zdrowia wydane na podstawie wspomnianego art. 31d ustawy o świadczeniach opieki zdrowotnej finansowanych ze środków publicznych. Obejmuje on świadczenia gwarantowane z zakresu: ratownictwa medycznego, podstawowej opieki zdrowotnej, programów zdrowotnych, leczenia szpitalnego; ambulatoryjnej opieki specjalistycznej, świadczeń wysokospecjalistycznych, zaopatrzenia w wyroby medyczne będące przedmiotami ortopedycznymi oraz środki pomocnicze, rehabilitacji leczniczej, leczenia stomatologicznego, opieki psychiatrycznej i leczenia uzależnień, lecznictwa uzdrowiskowego, świadczeń pielęgnacyjnych i opiekuńczych w ramach opieki długoterminowej oraz opieki paliatywnej i hospicyjnej.

$\mathrm{W} \S 12$ rozporządzenia mowa o drugim rodzaju pomocy dla pokrzywdzonych. Na cel ten przeznaczono 20\% ogólnej sumy środków pochodzących z nawiązek i świadczeń pieniężnych oraz spadków, zapisów, darowizn, dotacji, zbiórek i innych źródeł, które zostały uzyskane na finansowanie Funduszu. Mam tu na myśli działania jego dysponenta oraz podległych mu jednostek wymiaru sprawiedliwości polegające na organizowaniu i przeprowadzaniu akcji informacyjnych o prawach przysługujących pokrzywdzonym, organizowaniu i zlecaniu badań naukowych dotyczących sytuacji i potrzeb osób pokrzywdzonych, finansowaniu przygotowania, druku oraz kolportażu publikacji i wydawnictw poświęconych problematyce praw osób pokrzywdzonych, realizacji zadań służących tworzeniu sieci pomocy ofiarom przestępstw, organizowaniu konferencji, seminariów i spotkań poświęconych problematyce praw, sytuacji i potrzeb osób pokrzywdzonych, 
zlecaniu organizacji szkoleń dotyczących praw, sytuacji i potrzeb pokrzywdzonych, w szczególności dla osób odpowiedzialnych bezpośrednio za udzielanie im pomocy.

\subsubsection{Zadania w zakresie niesienia pomocy osobom pozbawionym} wolności i zwalnianym z jednostek penitencjarnych oraz źródła ich finansowania

Źródła, z których mogą pochodzić środki pieniężne służące realizowaniu zadań ze sfery pomocy postpenitencjarnej, są po części inne niż przewidziane na pomoc dla pokrzywdzonych. Stosownie do $\S 14$ rozporządzenia wchodzą tu bowiem w grę wszystkie - poza nawiązkami i świadczeniami pieniężnymi - wyszczególnione w art. $43 \S 7$ k.k.w.. $\mathrm{W} \S 14$ rozporządzenia sprecyzowano także, na czym ma polegać pomoc udzielana osobom pozbawionym wolności oraz zwalnianym z zakładów karnych i aresztów śledczych, jak też członkom ich rodzin. Katalog jej form jest bardzo obszerny. Obejmuje on: pokrywanie kosztów czasowego zakwaterowania lub udzielenie schronienia w ośrodku dla bezdomnych; okresową dopłatę do bieżących zobowiązań czynszowych za lokal mieszkalny, do którego osoba ubiegająca się o pomoc ma tytuł prawny, a lokal ten nie jest użytkowany przez inne osoby; organizowanie i finansowanie: poradnictwa prawnego, promocji zatrudnienia oraz aktywizacji zawodowej, szkoleń i kursów podnoszących kwalifikacje zawodowe oraz pokrywanie kosztów egzaminów potwierdzających kwalifikacje zawodowe, programów podnoszących kompetencje społeczne, których celem jest przeciwdziałanie czynnikom kryminogennym, a zwłaszcza agresji i przemocy z uwzględnieniem przemocy w rodzinie oraz problemu uzależnień; zakup materiałów, narzędzi, wyposażenia oraz urządzeń, a także odzieży i obuwia ochronnego niezbędnych do realizacji wymienionych programów oraz szkoleń i kursów podnoszących kwalifikacje zawodowe, a także do wykonywania nieodpłatnej pracy; pokrywanie kosztów: związanych ze specjalistycznym leczeniem lub rehabilitacją leczniczą oraz uzyskiwaniem orzeczeń o niepełnosprawności lub niezdolności do pracy, transportu specjalnego, zgodnie ze wskazaniami lekarskimi lub przejazdów do miejsca pobytu, nauki, terapii i pracy, wykonywanej zwłaszcza nie- 
odpłatnie, związanych z uzyskaniem dowodu osobistego oraz innych dokumentów niezbędnych do uzyskania pomocy, badań specjalistycznych wymaganych przy kwalifikowaniu do udziału w programach doskonalenia zawodowego i podnoszenia kompetencji społecznych oraz szkoleniach i kursach podnoszących kwalifikacje zawodowe oraz pracy wykonywanej nieodpłatnie, pokrywanie kosztów grupowego ubezpieczenia od następstw nieszczęśliwych wypadków osób zakwalifikowanych do udziału w szkoleniach i kursach oraz programach podnoszących kwalifikacje zawodowe i społeczne oraz pracy nieodpłatnej, promowanie i wspieranie inicjatyw oraz przedsięwzięć służących skutecznej readaptacji skazanych, działań o charakterze edukacyjnym i informacyjnym, organizowanie i prowadzenie szkoleń, organizowanie i zlecanie badań naukowych dotyczących sytuacji osób skazanych, i w końcu - pokrywanie kosztów związanych z organizacją i udzielaniem pomocy rzeczowej w postaci: żywności lub bonów żywnościowych, odzieży, bielizny, obuwia, środków czystości i higieny osobistej, biletów komunikacji publicznej, leków, środków opatrunkowych i sanitarnych, wyrobów medycznych, w tym przedmiotów ortopedycznych i środków pomocniczych, pomocy naukowych, dydaktycznych, książek i materiałów biurowych, niezbędnych przedmiotów wyposażenia domowego lub innych przedmiotów użytku osobistego wspomagających funkcjonowanie społeczne w miejscu zamieszkania lub pobytu, zwłaszcza osobom niepełnosprawnym, materiałów, narzędzi i wyposażenia niezbędnego do uczestnictwa w szkoleniach zawodowych, wykonywania wyuczonego zawodu lub prowadzenia na własny rachunek działalności gospodarczej; w szczególnie uzasadnionych przypadkach - przekazywanie świadczeń pieniężnych na określony cel i czas wskazany przez organ udzielający pomocy.

\subsection{Zasady udzielania pomocy}

\subsubsection{Subsydiarność}

Podstawową zasadą, która wyznacza zasięg udzielanej pomocy ze środków Funduszu wszystkim jego beneficjentom, jest zasada subsydiarności wprowadzona na mocy $\S 13$ art. 43 k.k.w. Stosownie do niej 
„Pomocy z Funduszu nie przyznaje się w takim zakresie, w jakim została ona udzielona z innych źródeł”.

2.3.2. Udzielanie pomocy osobom pokrzywdzonym i ich rodzinom

Jak już o tym była mowa, konkretna pomoc dla pokrzywdzonych i członków ich rodzin finansowana z przeznaczonych na nią środków Funduszu jest im udzielana za pośrednictwem stowarzyszeń, fundacji, organizacji i instytucji, które nie są zaliczane do sektora finansów publicznych i nie prowadzą działalności w celu osiagnnięcia zysku. Jednostki te mogą ubiegać się o uzyskanie dotacji celowej z Funduszu przeznaczonej na wspomaganie pokrzywdzonych.

Udzielenie pokrzywdzonemu pomocy jest więc dwuetapowe: najpierw o dotację z Funduszu musi wystapić do jego dysponenta jednostka, która ma świadczyć pomoc, a następnie - stosownie do §13 ust. 1 rozporządzenia - osoba uprawniona powinna złożyć wniosek o udzielenie pomocy do tej jednostki, choć jednostka ta może też zrobić to $\mathrm{z}$ własnej inicjatywy. $\mathrm{W} \S 13$ ust. 2 rozporządzenia określono wymogi pod adresem wniosku. Mianowicie ma on ,zawierać dane wnioskodawcy w zakresie niezbędnym do udzielenia pomocy, dokumenty potwierdzające okoliczności wskazane we wniosku, a także jego oświadczenie o wyrażeniu zgody na przetwarzanie jego danych osobowych w zakresie niezbędnym do rozpatrzenia wniosku i udzielenia pomocy".

\subsubsection{Udzielanie pomocy postpenitencjarnej}

Zasady udzielania pomocy postpenitencjarnej są inne niż te, które dotyczą udzielania pomocy osobom pokrzywdzonym.

$\mathrm{W} \S 15$ rozporządzenia wskazano, że udzielanie pomocy następuje na wniosek lub z urzędu, przy czym wniosek może pochodzić nie tylko od osoby uprawnionej, ale również od prokuratora, obrońcy, pełnomocnika oraz przedstawiciela skazanego, ustanowionego na podstawie art. $42 \S 1$ k.k.w. Wniosek powinien zawierać uzasadnienie dotyczące zakresu i celu pomocy. Należy nadto dołączyć do niego dokumenty potwierdzające okoliczności wskazane we wniosku, a w przypadku zwolnienia z jednostki penitencjarnej - dokument potwierdzający ten 
fakt. Adresatem wniosku jest dyrektor jednostki penitencjarnej, jeśli złożyła go osoba pozbawiona wolności lub zwalniana z takiej jednostki, a zawodowy kurator sądowy wówczas, gdy o uzyskanie pomocy ubiega się osoba już zwolniona z jednostki penitencjarnej albo członek jej rodziny, bądź też członek rodziny osoby pozbawionej wolności. Pomoc postpenitencjarna udzielana jest - w myśl regulacji zawartej w $§ 16$ rozporządzenia - na czas niezbędny „dla zrealizowania celów tej pomocy", na ogół jednak nie dłużej niż na okres 3 miesięcy, a w szczególności - do chwili uzyskania wsparcia ze środków pomocy społecznej. Możliwe jest jednak przedłużenie czasu jej świadczenia do 6 miesięcy w razie wystąpienia szczególnych okoliczności, jak choroba lub czasowa niezdolność do pracy. Pomoc w trakcie odbywania kary jest udzielana stosownie do zdiagnozowanych potrzeb w zakresie przygotowania do readaptacji społecznej, a jej forma, czas oraz warunki udzielania są ustalane $\mathrm{w}$ indywidualnym programie oddziaływania lub w programie wolnościowym obejmującym, jak wskazuje art. 164 k.k.w., okres 6 miesięcy poprzedzających warunkowe przedterminowe zwolnienie lub zakończenie wykonywania kary.

2.3.4. Konkurs ofert i umowa z podmiotem, który uzyskał dotację

W art. $43 \S 9$ k.k.w. ustawodawca wprowadził wymóg powierzania przez dysponenta Funduszu wykonywania zadań w zakresie udzielania pomocy „w trybie otwartego konkursu ofert”. Wymóg ten - zgodnie z $§ 2$ ust. 1 rozporządzenia - dotyczy wszystkich podmiotów działających na rzecz wspierania pokrzywdzonych, a podmiotów niosących pomoc postpenitencjarną wówczas, gdy nie należą do struktury systemu penitencjarnego.

Szczegóły dotyczące konkursu ofert zawiera ust. 2 \& rozporządzenia. Określono w nim warunki formalne, jakie winno spełniać ogłoszenie otwartego konkursu ofert, a mianowicie wskazanie rodzaju zadania, wysokości dotacji celowej przeznaczonej na jego realizację, sposobu jej przyznawania, terminów i warunków realizacji zadania, terminu składania ofert, jak też terminu, trybu i kryteriów dokonywania wyboru oferty. Z kolei oferta powinna - stosownie do $\S 3$ rozporządzenia - określać sposób, termin i miejsce realizacji zadania, wysokość wnio- 
skowanej dotacji, jak również zawierać informację o dotychczasowej działalności podmiotu w sferze związanej z danym zadaniem oraz posiadanych zasobach rzeczowych, zapleczu kadrowym i jego kompetencjach zapewniających wykonanie zadania oraz o wysokości środków finansowych pozyskanych na wykonanie zadania z innych źródeł.

$\mathrm{W} \S 5$ rozporządzenia jest mowa o kryteriach oceny ofert przez dysponenta Funduszu. Wskazano, że w tym zakresie bierze się pod uwagę: możliwość realizacji zadania przez podmiot ubiegający się o dotację, przedstawioną kalkulację kosztów jego wykonania oraz poziom współfinansowania zadania z innych źródeł.

Pierwszy konkurs ofert (na rok 2012) został ogłoszony 18 maja 2012 r. Jego adresatami były wyłącznie organizacje mające w polu swojego widzenia wszystkie bez wyjątku kategorie pokrzywdzonych. Z góry zostały więc wyeliminowane jako potencjalni beneficjenci podmioty wyspecjalizowane $\mathrm{w}$ niesieniu pomocy jakiejś konkretnej grupie pokrzywdzonych, jak np. kobiety lub dzieci, bądź też ofiary przemocy domowej, wypadków komunikacyjnych, zabójstw czy podpaleń. Wyniki konkursu zostały ogłoszone 9 sierpnia 2012 r. - i zadziwiły. Okazało się, że dysponent Funduszu nie uczynił zadość wprowadzonemu przez siebie ograniczeniu. Wśród ośmiu podmiotów, którym przyznano dotację, znalazły się bowiem takie, które z całą pewnością swoją działalnością nie obejmują wszystkich grup ofiar wszystkich typów przestępstw, jak w szczególności toruńska Fundacja na Rzecz Ofiar Wypadków Drogowych „Liść”, warszawska Fundacja Dzieci Niczyje, czy też Stowarzyszenie „SOS dla Rodziny” ze Szczecina ${ }^{17}$. Czym wyjaśnić tę sytuację - doprawdy trudno dociec.

Przyznanie dotacji z Funduszu następuje na drodze zawarcia z podmiotem, który ją otrzymał, umowy (art. 43 § 10 k.k.w.i $§ 9$ rozporządzenia).

Uwage zwraca fakt wprowadzenia obowiązku bardzo drobiazgowej i wielopoziomowej sprawozdawczości, jakim zostały obarczone wszystkie podmioty mające cokolwiek wspólnego z dotacjami przyzna-

17 Szczegóły na stronie Ministerstwa Sprawiedliwości. 
wanymi z Funduszu ${ }^{18}$, jak również przewidywanie licznych czynności kontrolnych w tym zakresie. Ma to - jak podniesiono w Uzasadnieniu projektu ustawy z 12 lutego 2010 r. - sprzyjać właściwemu wykorzystywaniu środków pochodzących z Funduszu ${ }^{19}$. W załączniku do rozporządzenia zamieszczono wzór „Kwartalnej informacji o wykorzystaniu środków otrzymanych z Funduszu Pomocy Pokrzywdzonym oraz Pomocy Postpenitencjarnej za okres od początku roku do końca ... kwartału ... roku", który potwierdza dokonane spostrzeżenie.

Warto zaznaczyć, że unormowanie kwestii otwartego konkursu ofert jest zbieżne z trybem przewidzianym w odniesieniu do przekazywania wykonania określonych zadań organizacjom pożytku publicznego przez podmioty administracji publicznej. Mowa o tym w art. 13 i n. ustawy z 14 kwietnia 2003 r. o działalności pożytku publicznego i wolontariacie ${ }^{20}$.

\subsection{Konsekwencje niewłaściwego wykorzystania środków}

Dotacja z Funduszu jest dotacją celową, co jest równoznaczne z tym, że przeznaczona jest na zrealizowanie ściśle określonego przedsięwzięcia. W art. 43 k.k.w. zamieszczone zostały stosunkowo liczne, w porównaniu z normującymi inne kwestie, zapisy odnoszące się do sytuacji wykorzystania środków pochodzących z Funduszu niezgodnie $\mathrm{z}$ ich przeznaczeniem.

Stwierdzenie takiego faktu skutkuje obowiązkiem podmiotu do zwrotu równowartości otrzymanych środków finansowych wraz z odsetkami ( 15 art. 43 k.k.w.), a osoby, która uzyskała pomoc - do zwrotu równowartości uzyskanych świadczeń (§ 16 ww. art.). Ta ostatnia zarazem - jeżeli nie dokona zwrotu pomimo wezwania - „traci prawo do dalszej pomocy, chyba że zachodzą wyjątkowe okoliczności uzasadniające udzielenie jej takiej pomocy" (§ 18 ww. art.).

18 Kwestiom tym poświęcone sąprzepisy zamieszczone w rozdziale 4.,„Szczegółowe zasady gospodarki finansowej Funduszu” (§ 17-21) rozporządzenia.

19 Zob. s. 10.

20 Tekst jedn. Dz. U. z 2010 r. Nr 234, poz. 1536. 


\section{O KONTROWERSYJNOŚCI PRZYJĘTYCH ROZWIAZZAŃ}

Podstawowe zastrzeżenie sprowadza się do tego, że Fundusz stanowi dowód włączenia w sferę regulacji karno wykonawczych kwestii dotyczących niesienia pomocy osobom pokrzywdzonym przestępstwami.

Prawo karne wykonawcze, jak wynika to z treści art. $1 \S 1$ k.k.w., ma za swój przedmiot wykonywanie prawomocnych orzeczeń sądowych, w tym tych, które zapadają w postępowaniu karnym wobec sprawców przestępstw. Regulacje karno wykonawcze dotyczą zatem wyłącznie osób skazanych. Zasadne jest zatem uwzględnienie w nich przepisów dotyczących pomocy postpenitencjarnej, ale z całą pewnością nie takich, których przedmiotem jest pomoc dla pokrzywdzonych. Wobec nich nic się bowiem nie orzeka $\mathrm{i}$ - w konsekwencji - również niczego się nie wykonuje. Ustawodawca faktu tego nie wziął w ogóle pod uwagę. Stanął na stanowisku, że skoro przepisy k.k.w. normują kwestię udzielania pomocy postpenitencjarnej, to równie dobrze mogą odnosić się do pomocy dla pokrzywdzonych przestępstwami. Nic bardziej błędnego i jednocześnie naruszającego dobro, a w szczególności godność tych ostatnich. Nie jest naprawdę obojętne, czy są oni traktowani tak samo, jak sprawcy przestępstw, czy też jednak inaczej. Utworzenie Funduszu na mocy przepisów k.k.w. można zatem uznać za kolejny przejaw niewłaściwego rozumienia istoty potrzeb ofiar przestępstw i zasad ochrony ich interesów, czego skutkiem jest w dużej mierze jedynie pozorowanie działań na ich rzecz ${ }^{21}$.

${ }^{21}$ Problem ten ujawnił się szczególnie ostro na tle regulacji dotyczących systemu dozoru elektronicznego - zob. zwłaszcza: E. BIEŃKowsKA, Zakaz zbliżania się do pokrzywdzonego przez skazanego odbywajacego karę pozbawienia wolności $w$ systemie dozoru elektronicznego - kontrowersyjna regulacja, [w:] Węzłowe problemy prawa karnego, kryminologii i polityki kryminalnej. Ksiega pamiatkowa ofiarowana Profesorowi Andrzejowi Markowi, pod red. V. KonARSKIEJ-WrzoseK, J. LACHOWSKIEGO, J. Wóscikiewicza, Warszawa 2010, s. 833 i n; TeJże, Nowelizacja przepisów o zakazie zblizania się do pokrzywdzonego przez skazanego odbywajacego kare pozbawienia wolności w systemie dozoru elektronicznego - czy wystarczajaca?, [w:] Teoretyczne $i$ praktyczne problemy współczesnego prawa karnego. Księga jubileuszowa dedykowana Profesorowi Tadeuszowi Bojarskiemu, pod red. A. MichalskiEJ-Warias, I. Nowikowskiego, J. Piórkowskiej-Flieger, Lublin 2011, s. 821 i n. 
Skupienie w jednym Funduszu środków przeznaczonych na pomoc postpenitencjarną oraz na pomoc dla pokrzywdzonych jest zresztą absolutnie sztuczne. Wynika to stąd, że - jak dowodzą tego jednak dopiero unormowania aktu wykonawczego - są one w zasadzie finansowane z różnych źródeł oraz odrębnie księgowane, a nadto dystrybucja zgromadzonych środków finansowych odbywa się w większości na całkowicie odmiennych zasadach. W praktyce zatem i tak funkcjonują dwa odrębne fundusze. Co więcej - w sposób uprzywilejowany pod względem zagwarantowania środków finansowych został unormowany Fundusz w tej części, która dotyczy świadczenia pomocy postpenitencjarnej.

Spośród wskazanych w art. $43 \$ 7$ k.k.w. źródeł finansowania działalności Funduszu na pomoc dla pokrzywdzonych przeznaczono środki finansowe uzyskane $\mathrm{m}$. in. z zasądzonych przez sądy nawiązek i świadczeń pieniężnych. Zasądzanie wskazanych środków karnych jest jednak tylko fakultatywne i możliwe wyłącznie w ściśle określonych przypadkach. Co więcej, nałożenie na sądy orzekające obowiązku ich egzekwowania (§ 3-5 art. 43 k.k.w.) może je zniechęcać do wydawania orzeczeń na rzecz Funduszu. Wiąże się to bowiem z poszerzeniem zakresu zadań ciążących na tych organach przy braku zapewnienia choćby dodatkowych etatów. O tym pomyślano tylko w odniesieniu do dysponenta Funduszu.

Biorąc pod uwage natomiast źródła finansowania działalności w obrębie pomocy postpenitencjarnej, przychody na ten cel pochodzą m.in. z obowiązkowych stałych potrąceń z wynagrodzenia za pracę skazanych oraz z takich potrąceń o charakterze okresowym dokonywanych w wyniku wykonywania kar dyscyplinarnych. Wieloletnie już doświadczenia dotyczące funkcjonowania Funduszu Pomocy Postpenitencjarnej pozwalają bez wątpienia na to, by w miarę precyzyjnie określić, jakiego rzędu wpływów z tych tytułów można się spodziewać.

Ustawodawca przewidział, że Fundusz w obu jego członach może być zasilany finansowo także z takich źródeł, jak spadki, zapisy, darowizny oraz dotacje, zbiórki i innych. Podnieść należy, iż pierwotnie przewidywano finansowanie $\mathrm{z}$ tych źródeł jedynie pomocy postpe- 
nitencjarnej, co oczywiście prowadziło do wniosku, że twórcy omawianej instytucji bardziej dbali o zabezpieczenie podstaw działalności postpenitencjarnej niż w sferze niesienia pomocy pokrzywdzonym. Wprowadzone rozwiązanie należy uznać za wyraźnie właściwsze. Problem tylko w tym, by podmioty chcące wspomagać działalność Funduszu otrzymały klarowną informację co do sposobu wskazania, która jego część pragną zasilić, np. poprzez wprowadzenie odrębnych kont dla każdej z nich. Tymczasem, jak głosi § 17 ust. 1 rozporządzenia, „Fundusz prowadzi wyodrębniony rachunek bankowy”, a to oznacza, że jest on jeden. Nie ma również wzmianki o tym, aby na tym rachunku istniały subkonta.

Zwróćmy też uwagę na jeszcze inną kwestię, mianowicie na to, czym skutkuje zaliczenie danej instytucji do kategorii funduszy celowych. Otóż, następstwem jest fakt, że jego działanie podlega reżimowi przepisów ustawy z 27 sierpnia 2009 r. o finansach publicznych ${ }^{22}$, która $\mathrm{m}$. in. określa zakres i zasady działania państwowych funduszy celowych (art. 1 pkt 2 in fine). Przepisy te stanowią w szczególności, że wchodzą one jako jednostki budżetowe w skład sektora finansów publicznych (art. 9 pkt 7), co obliguje do stosowania zasad gospodarki finansowej określonych w tej ustawie (art. 10 ust. 1). Wiąże się z tym konieczność sporządzenia rocznego planu finansowego jako podstawy gospodarki finansowej w danym roku budżetowym (art. 29 pkt 6). Mowa o tym w $\S 18$ rozporządzenia. Plan taki zostaje uwzględniony w ustawie budżetowej na dany rok kalendarzowy, a dysponent funduszu celowego musi go wykonać. Stąd w ust. 3 wspomnianego przepisu rozporządzenia znalazł się zapis zobowiązujący Ministra Sprawiedliwości do zapewnienia zgodności projektu planu z projektem ustawy budżetowej. Wynika to $\mathrm{z}$ faktu, że dochody pobierane przez państwowe jednostki budżetowe, a więc również przez fundusze celowe, stanowią dochody budżetu państwa ${ }^{23}$. W Rządowym projekcie ustawy budżetowej na rok $2012^{24}$ przewidziano planowane przycho-

22 Dz. U. Nr 157, poz. 1240 ze zm.

${ }_{23}$ Zob. art. 111 pkt 7 ww. ustawy.

${ }^{24}$ Druk sejmowy nr 4694. 
dy Funduszu w kwocie 34000 złotych. Ciekawe, że w Uzasadnieniu do Rządowego projektu położono szczególny nacisk na fakt, iż kwota ta jest wyższa o 10000 złotych od tej, która dotyczyła poprzedniego, 2011 r. ${ }^{25}$.Czyżby nie dostrzeżono, że Fundusz nie jest już taki sam jak rok temu? Zastanawia ponadto wskazanie w Uzasadnieniu, iż środki Funduszu mają być przeznaczane nie tylko na konkretną pomoc dla pozbawionych wolności i zwalnianych z jednostek penitencjarnych oraz członków ich rodzin, jak też dla pokrzywdzonych i członków ich rodzin, ale również na ,wsparcie i rozwój systemu pomocy osobom pokrzywdzonym przestępstwem oraz pomocy postpenitencjarnej (nowe zadania)"26. Stwierdzenie to dziwi, ponieważ nie do końca jest zgodne z obowiązującą regulacją prawną.

W $\S 2$ ust. 2 pkt 1 rozporządzenia wskazano, że otwarty konkurs ofert może dotyczyć zadań wymienionych w art. $43 \S 8$ pkt. 1, 3 i 4 k.k.w. W tym trzecim mowa o działalności na rzecz rozwijania systemu pomocy dla pokrzywdzonych oraz systemu pomocy postpenitencjarnej. Tymczasem w $\S 10$ rozporządzenia wyraźnie zastrzeżono, że „Przyznane dotacje celowe mogą być przeznaczone wyłącznie na cele wskazane w $\S 11$ i 14 ". W katalog konkretnych form pomocy postpenitencjarnej zawarty w $\S 14$ wpleciono również zadanie w postaci wspierania i rozwijania tej działalności. Jest to równoznaczne z tym, że na jego realizację mogą być przyznawane dotacje celowe. Inaczej jest jednak w odniesieniu do pokrzywdzonych. W tym przypadku o zadaniach z zakresu rozwijania i wspierania systemu pomocy dla nich jest mowa w oddzielnym przepisie, którym jest $\S 12$ rozporządzenia. Czy z Funduszu mogą być zatem przyznawane dotacje na taką działalność stosownie do regulacji zawartej w $\S 2$ ust. 2 pkt 1 rozporządzenia, czy też nie, ponieważ nie wspomina o tym $\S 10$ tego aktu prawnego? Trudno odpowiedzieć, ponieważ mamy do czynienia z istotną sprzecznością unormowań dotyczących tej kwestii.

Co się tyczy środków na rzecz niesienia pomocy pozbawionym wolności, nie wiadomo, jak ma się kształtować - z jednej strony - ich

\footnotetext{
25 J.w., T. I. Uzasadnienie, s. 167-168.

26 J.w., s. 167.
} 
podział pomiędzy podmioty z systemu penitencjarnego i spoza niego, a drugiej - na świadczenie bezpośredniej pomocy i na działalność edukacyjno-informacyjna. Brak jakichkolwiek regulacji w tym zakresie stanowi z pewnością kolejny mankament przyjętego rozwiązania.

Zwrócić trzeba nadto uwagę na unormowanie dotyczące świadczenia bezpośredniej pomocy pokrzywdzonym przez podmioty, którym zostały przyznane dotacje celowe z Funduszu. Warunkiem uzyskania takiej pomocy jest $\mathrm{m}$. in. wyrażenie zgody na przetwarzanie danych osobowych (§ 13 ust. 2 rozporządzenia). Wymóg taki pojawił się dopiero $\mathrm{w}$ obowiązującym rozporządzeniu. W Uzasadnieniu jego projektu jedynie odnotowano ten fakt ${ }^{27}$. Regulacji tej nie można wszakże pozostawić bez komentarza. Wynika to stąd, że analogicznego rozwiązania nie przewidziano w odniesieniu do osób korzystających z pomocy postpenitencjarnej świadczonej przez podmioty spoza systemu państwowego. Powstaje pytanie: dlaczego?

Ustawa z 29 sierpnia 1997 r. o ochronie danych osobowych ${ }^{28}$ stanowi, że generalnie zabrania się przetwarzania tzw. danych wrażliwych, w tym m.in. danych o skazaniach, choć dopuszczone są wyjątki od tego zakazu, np. wyrażenie na to pisemnej zgody (art. 27). Jednakże z pomocy postpenitencjarnej korzystają nie tylko skazani na karę pozbawienia wolności, ale również tymczasowo aresztowani i członkowie rodzin obu tych grup osób. W odniesieniu do nich nie można przecież mówić o ,skazaniach”. Dlaczego zatem - ponówmy pytanie zostali potraktowani inaczej, w sposób bardziej uprzywilejowany, niż pokrzywdzeni i ich rodziny? Przyjęte rozwiązanie wskazuje, że bez wyrażenia zgody na przetworzenie danych uzyskanie przez tych ostatnich pomocy od podmiotu, któremu została przyznana dotacja celowa z Funduszu, jest niemożliwe.

Przywołam tu - bardzo ważną w kontekście omawianego zagadnienia - opinię Europejskiego Inspektora Ochrony Danych, w której nakazał on prawodawcy unijnemu zwrócenie baczniejszej uwagi

27 Rozporządzenie Ministra Sprawiedliwości (do podpisu, bez daty) w sprawie Funduszu Pomocy Pokrzywdzonym oraz Pomocy Postpenitencjarnej, Uzasadnienie, s. 18.

${ }^{28}$ Tekst jedn. Dz. U. z 2002 r. Nr 101, poz. 926 ze zm. 
na zapewnienie odpowiednich gwarancji ochrony danych osobowych ofiar przestępstw ${ }^{29}$. Warto o tym pamiętać.

W Uzasadnieniu projektu ustawy z 12 lutego 2010 r. wiele miejsca poświęcono potrzebie utworzenia ogólnopolskiego spójnego i skutecznego systemu pomocy ofiarom przestępstw. Podniesiono, że właśnie powołanie do życia Funduszu będzie sprzyjać realizacji tego celu, ponieważ pozwoli na skuteczniejsze egzekwowanie orzeczeń, zapewni efektywniejsze wykorzystywanie przez organizacje pozarządowe środków finansowych, a przede wszystkim da im gwarancję stabilności i przewidywalności ich pozyskiwania ${ }^{30}$.Takie argumenty nie trafiły jednak do przekonania organizacjom pozarządowym i trudno zresztą temu się dziwić.

W interpelacji z 10 listopada 2009 r. w sprawie zagrożeń wynikających z utworzenia Funduszu Pomocy Pokrzywdzonym oraz Pomocy Postpenitencjarnej poseł W. Żukowski podniósł w szczególności, iż regulacja ta ,sprawi, że sądy utracą swobodę w orzekaniu nawiązek czy świadczeń na rzecz zarejestrowanych podmiotów lokalnych (fundacji, stowarzyszeń). Jest powszechnie znany fakt, że sądy lokalne posiadają najlepszą wiedzę, kto zasługuje na wsparcie. W opinii środowisk lokalnych poprzez centralizację zadań zostaną one pozbawione bardzo poważnych środków finansowych, które były kierowane na najbardziej potrzebujących. Pojawiający się argument usprawnienia ściaggalności zasądzanych nawiązek w praktyce powinien skupić się na wzmocnieniu skuteczności wykonywania wyroków sądowych, a nie koncentrować się na braku możliwości prawnych ściągania nawiązek przez fundacje czy stowarzyszenia"31. Ministerstwo Sprawiedliwości

${ }^{29}$ Opinia Europejskiego Inspektora Ochrony Danych w sprawie pakietu legislacyjnego dotyczącego praw ofiar przestępstw, w tym wniosku dotyczącego dyrektywy ustanawiającej normy minimalne w zakresie praw, wsparcia i ochrony ofiar przestępstw oraz wniosku dotyczącego rozporządzenia w sprawie wzajemnego uznawania środków ochrony w sprawach cywilnych (2012/C 35/02 z 17 października 2011 r., Dz. Urz. UE C 35/10 z 9.2.2012 r., t. 8 i n.

${ }^{30}$ Zob. Uzasadnienie..., s. 5 i n.

${ }^{31}$ Interpelacja nr 12979 na stronach Sejmu. 
podtrzymało swoje stanowisko ${ }^{32}$. Trudno jednak byłoby nie uznać, że pogląd wyrażony $\mathrm{w}$ interpelacji zasługuje w dużej mierze na aprobatę. Czym innym jest bowiem orzekanie na rzecz znanej ze swojej dotychczasowej działalności i cenionej organizacji, a czym innym na rzecz podmiotu, o którym nie tylko nic się nie wie, ale nie wie się również, na jaki cel przeznaczy on ewentualnie zasądzone środki karne.

Oznacza to, że dysponent Funduszu zagwarantował sobie możliwość prawną faktycznego uzyskiwania kwot pochodzących ze wskazanych źródeł, jakich organizacjom pozarządowym nie przyznano. Pamiętać przy tym należy, iż kwoty zasądzone w postępowaniu karnym na rzecz Skarbu Państwa podlegają egzekucji w pierwszej kolejności. Dotyczyło to grzywien i kosztów sądowych, a obecnie odnosi się również do środków karnych zasądzonych na rzecz Funduszu. Pokrzywdzeni natomiast wówczas, gdy uzyskają orzeczenie obowiązku naprawienia szkody lub zadośćuczynienia, są w zasadzie pozostawieni sami sobie i moga w ogóle nie zostać zaspokojeni. Po wyegzekwowaniu od sprawcy lub sprawców tego, co należy się państwu, mogą się oni okazać po prostu niewypłacalni. Czy więc rzeczywiście utworzenie Funduszu służy ochronie interesów i poprawieniu sytuacji pokrzywdzonych?

\section{WNIOSKI KOŃCOWE}

Przedstawione rozważania dowodzą jasno, że nie jestem zwolenniczką nowej instytucji. W zasadniczej mierze wynika to stąd, że kwestia pomocy dla pokrzywdzonych stała się materią prawa karnego wykonawczego, a ściślej - prawa penitencjarnego. Uwłacza to ich godności stawiając na równi ze sprawcami przestępstw, i to tymi pozbawionymi wolności. Tymczasem stosownie do art. $30 \mathrm{zd}$. 2 Konstytucji RP z 2 kwietnia 1997 r. obowiązkiem władz publicznych jest poszanowanie i ochrona godności człowieka ${ }^{33}$. Dlatego za całkowite nieporozumienie uważam głoszenie, że „Dla samych pokrzywdzonych nazwa Funduszu

32 Zob. stanowisko na stronach Sejmu.

33 Dz. U. Nr 78, poz. 483 ze zm.; szerzej m.in. W. SkrzydŁo, Konstytucja Rzeczypospolitej Polskiej. Komentarz, Warszawa 2009, s. 37 i n . 
nie będzie miała oczywiście istotnego znaczenia. Najważniejsze, by dzięki nowym regulacjom otrzymali realną pomoc"34.

Dla nikogo nie jest obojętne, jak nazywa się instytucja, z której usług ma korzystać. To po pierwsze, a po drugie - poważne wątpliwości budzi przekonanie o uzyskiwaniu przez pokrzywdzonych -właśnie za sprawą powołania do życia Funduszu - owej „realnej pomocy”. Przekonują o tym zaprezentowane regulacje prawne. Podkreślmy, że nie wiadomo, jakiego rzędu środki finansowe mogą wpływać do Funduszu z nawiązek i świadczeń pieniężnych, ponieważ opieranie się w tym względzie na dotychczasowych doświadczeniach może okazać się całkowicie chybione. Nie do końca przejrzyste są także zasady przyznawania dotacji, to zaś może prowadzić do faworyzowania jednych organizacji, a pomijania innych. Organizacje będą więc poważnie uzależnione od dysponenta Funduszu, który może istotnie wptywać na sposób i rodzaj ich działalności, kierując się przede wszystkim potrzebą utworzenia sieci pomocy ofiarom przestępstw. Nie zawsze przyniesie to dobre efekty, ponieważ lokalne potrzeby mogą być bardzo zróżnicowane i nieporównywalne, jak też niezbyt dobrze znane dysponentowi.

Razi upatrywanie zalety utworzenia jednego Funduszu dla pokrzywdzonych i pozbawionych wolności w tym, że - jak o tym była mowa w przytoczonym na wstępie fragmencie Uzasadnienia projektu ustawy z 12 lutego 2010 r. - scentralizowanie środków finansowych pozwoli ,na zachowanie uzasadnionych interesem społecznym prawidłowych proporcji” w obu tych sferach, jak też ,zapewni racjonalne wydatkowanie środków finansowych". Nic podobnego, ponieważ Fundusz w obu swych segmentach funkcjonuje na odmiennych zasadach i w oparciu o inne źródła przychodów. Powstał zatem zupełnie sztuczny twór, którego oba człony w ogóle do siebie nie przystają i nie mają ze sobą nic wspólnego. Co więcej - owa centralizacja pozostaje w całkowitej sprzeczności z dążeniem do budowania społeczeństwa obywatelskiego.

34 Tak M. KRUK, Nowy fundusz - realna pomoc pokrzywdzonym, «Na Wokandzie. Kwartalnik Informacyjny Ministerstwa Sprawiedliwości» 1/2010, s. 19. 
Ostatnie zastrzeżenie, nie mniej ważne od już zgłoszonych, dotyczy samej nazwy Funduszu, a w szczególności wprowadzenia do niej terminu ,pokrzywdzony" 35 . Jest to pojęcie - z jednej strony - nazbyt wąskie, bowiem określa wyłącznie status procesowy w postępowaniu karnym. Jeśli więc postępowanie takie nie jest prowadzone, pokrzywdzonym formalnie się nie jest. Z drugiej strony jest ono zbyt szerokie: odnosi się nie tylko o osób fizycznych (art. 49 k.p.k.). Tymczasem gdy mówimy o wspieraniu i pomocy dla tych, którzy doznali przestępstwa, mamy na myśli właśnie takie osoby, a nie np. osoby prawne. Wynika to jasno z treści dokumentów międzynarodowych z Decyzją ramową Rady w sprawie pozycji ofiar w postępowaniu karnym z 15 marca 2001 r. (2001/220/WSiSW) ${ }^{36}$ na czele. W jej art. 1 pkt a) zostało zdefiniowane pojęcie ofiary przestępstwa, nie zaś pokrzywdzonego, jako odnoszące sie do osób fizycznych. W taki też sposób interpretuje postanowienia Decyzji Europejski Trybunał Sprawiedliwości ${ }^{37}$.

Określenie użyte w nazwie Funduszu może być zatem po prostu mylące. Warto bowiem dodać, że co prawda Fundusz ma m.in. służyć tworzeniu i rozwijaniu „Sieci Pomocy Ofiarom Przestępstw”, ale wchodzące w jej skład podmioty - to „Ośrodki Pomocy dla Osób Pokrzywdzonych Przestępstwem".

W konkluzji trzeba stwierdzić, że utworzenie Funduszu Pomocy Pokrzywdzonym oraz Pomocy Postpenitencjarnej jako wspólnego dla obu grup beneficjentów nie było niczym uzasadnione. Za sprawą takiego unormowania ofiara przestępstwa może doznać jednak niepotrzebnych, dalszych stresów, które nie są rezultatem samego przestępstwa, lecz jej późniejszego, niewłaściwego traktowania. Może więc doznać

35 Zob. też C. Kulesza, Projekt Europejskiej Dyrektywy z dnia 18 maja 2011 r. w sprawie wsparcia i ochrony ofiar w świetle prawa polskiego, «Prokuratura i Prawo» 12/2011, s. 5 i n.

36 Dz. Urz. UE L 82/1 z 22.03.2001 r.; także w: E. BieńKowsKa, L. Mazowiecka, Ofiara przestępstwa..., s. 131 i n.; zob. też E. BIEŃKOwsKA, Sytuacja ofiar przestępstw w postępowaniu karnym w świetle standardów Unii Europejskiej, «Studia Prawnicze» 3-4/2001, s. 37 i n.

37 Dokonał tego w wyrokach wydanych w trybie prejudycjalnym z 28 czerwca 2007 r. w sprawie C-467/05 i z 21 października 2010 r. w sprawie C-205/09. 
wiktymizacji wtórnej, którą generuje - pogłębiając bezpośrednie negatywne skutki przestępstwa określane mianem wiktymizacji pierwotnej - sama regulacja prawna tylko ze względu na swój kształt ${ }^{38}$.

\section{Crime Victims and the Polish Postpenitentiary Assistance Fund: A Critical Assessment of a New Institution for Executive Penal Law}

\section{Summary}

The paper describes and analyses the regulation of a Fund which has been in operation since January 1st, 2012. The idea behind the Fund was to establish a centralised system for the management and fair distribution of financial resources allocated to assist crime victims and persons discharged from penitentiary institutions. Paradoxically, however, the two parts of the Fund come from separate sources.

In the author's opinion it is completely unacceptable to incorporate a regulation concerning victims of crime in the executive code of penal law, which regulates the execution of penalties imposed on perpetrators of crime and is not concerned with crime victims at all.

The analysis of the details of the Fund shows that the legislator's main intention was to find financial justification for his own activity and to create a means of control over non-governmental organisations assisting crime victims.

38 Zob. na ten temat więcej zwłaszcza: E. BIEŃKowsKA, Wiktymizacja wtórna geneza, istota $i$ rola $w$ przeksztatcaniu polityki traktowania ofiar przestępstw, [w:] Wiktymizacja wtórna. Geneza, istota i rola w przeksztatcaniu polityki traktowania ofiar przestępstw, pod red. L. MAzowiecKIEJ, Warszawa 2012, s.53 i n.; TejżE, Wiktymizacja wtórne - niepożadany dodatkowy skutek przestępstwa, [w:] Mediacje w społeczeństwie otwartym. Prawne, społeczne i ekonomiczne aspekty prowadzenia mediacji w obszarze działania władz publicznych, pod red. M. TABERnACKIEJ, R. RASZEWSKIEJ-SKAŁECKIEJ, Wrocław 2012, s. 83 i n. 